Actor-Network Theory and Sentiment Analysis on Regional Development Issues and Politics in Social Media

Teori Aktor-Jaringan dan Analisis Sentimen Isu Pembangunan Daerah dan Politik di Media Sosial

\title{
Actor-Network Theory and Sentiment Analysis on Regional Development Issues and Politics in Social Media
}

\section{Teori Aktor-Jaringan dan Analisis Sentimen Isu Pembangunan Daerah dan Politik di Media Sosial}

\author{
Yerik Afrianto Singgalen ${ }^{1}$ \\ ${ }^{1}$ Atma Jaya Catholic University of Indonesia, Jl. Jenderal Sudirman 51, Jakarta 12930* \\ Email: yerik.afrianto@atmajaya.ac.id
}

Masuk tanggal : 15-10-2020, revisi tanggal : 19-01-2021, diterima untuk diterbitkan tanggal : 11-02-2021

\begin{abstract}
During the Covid-19 pandemic, North Halmahera Regency's political activity became intense in virtual spaces, especially on the Facebook group Quovadis North Halmahera. The things discussed in the virtual space have an impact on the community in the real world. Hate Speech and provocative issues generate negative responses in the real world, marked by conflicts in several social spaces. This article aims to discuss regional development issues and politics in social media based on sentiment analysis and actornetwork theory. This article also identifies the vulnerability aspect by mapping and classifying netizen's argument in the virtual space to various regional development issues based on economic, social, cultural, political, tourism, and environmental aspects. This research uses qualitative methods. The process of collecting data uses in-depth interview techniques, observation, and document study. Data processing uses triangulation techniques. Also, research instruments used are QGIS 2.18 .4 and Nvivo 12 Plus applications for mapping research sites and mapping development issues in virtual space, namely Quo Vadis Halmahera Utara Facebook group. This study indicates that social capital (Norm, Trust, Network) becomes an aspect of vulnerability based on mapping and content analysis in virtual space according to netizens' response to development issues in the North Halmahera Regency. Furthermore, the contents containing hate speech elements, invalid information (hoax), sarcasm, bullying, and privacy attacks are the potential actors to cause social capital degradation based on the Actor-Network-Theory.
\end{abstract}

Keywords: actor-network theory, sentiment analysis, regional development, politics, social media

\begin{abstract}
Abstrak
Selama Pandemi Covid-19, kondisi perpolitikan di Kabupaten Halmahera Utara menjadi intensif di ruang virtual, khususnya grup facebook QuoVadis Halmahera Utara. Pelbagai isu pembangunan dan politik di ruang virtual tersebut berdampak terhadap kondisi sosial masyarakat di kehidupan sehari-hari. Ujaran kebencian, isu profokatif hingga sentimen negatif memantik konflik di ruang sosial. Artikel ini bertujuan untuk mendiskusikan masalah pembangunan dan politik di media sosial berdasarkan analisis sentimen dan teori jejaring aktor. Artikel ini juga mengidentifikasi aspek kerentanan, dengan memetakan dan mengklasifikasikan argumen netizen di ruang virtual, menanggapi pelbagai persoalan sosial, budaya, politik, pariwisata dan lingkungan. Penelitian ini menggunakan metode
\end{abstract}


kualitatif. Proses pengolahan data menggunakan teknik wawancara mendalam, observasi dan studi dokumen. Proses pengolahan data menggunakan trianggulasi. Instrumen penelitian yang digunakan ialah QGIS 2.18.4 untuk pemetaan lokasi atau wilayah penelitian dan Nvivo 12 Plus untuk pemetaan isu pembangunan dan politik yang didiskusikan dalam grup facebook Quovadis Halmahera Utara. Hasil penelitian ini menunjukkan bahwa modal sosial (norma, kepercayaan, jejaring) menjadi aspek kerentanan. Selain itu, konten yang teridentifikasi dari hasil analisis sentimen ialah ujaran kebencian, informasi yang tidak valid, sarkasme, perundungan dan penyerangan privasi, sebagai penyebab degradasi modal sosial berdasarkan teori jejaring aktor.

Kata Kunci: analisis sentimen, media sosial, pembangunan daerah, politik, teori jejaring aktor

\section{Introduction}

The development of communication access through the expansion of the internet network to the 3T area Tertinggal, Terdepan, Terluar (Disadvantaged, Frontier, and Outermost) encourages the development of information technology in Indonesia. Social media-based applications and the increasing intensity of users also form a new identity in the virtual space as netizens. The popularity of social media in Indonesia has brought collective action changes to guard government policies in realizing equitable development. Social media is seen as useful in encouraging social movements in Indonesia (Molaei, 2015). Also, social media's effectiveness in politics causes social media use as a medium for political campaigns (Kartikatantri, Hafiar, \& Priyatna, 2015; Lim, 2013; Prilani \& Hutomo, 2020). social media is also a means of controlling government programs by the community, such as the anti-mining campaign on Bangka Island, Indonesia (Großmann, 2018). Social media is also a means of strengthening Indonesia's religious values (Halim, 2018; Hew, 2018). In its development, social media misuse through irresponsible content has also become a threat to nationalism in Indonesia (Lim, 2017). The communication access to the development and use of social media applications in Indonesia has positive and negative sides that need to be controlled. Social media can be a place to capture people's aspirations effectively and efficiently in the era of the Industrial Revolution 4.0.

Social media has become a famous study of academics in economics and politics (Bratich, 2014; Gyampo, 2017). The study of social interaction on social media raises scientific debates about the controversy over the effectiveness of social media use in virtual spaces that intervene in community formation and social networks (Rodríguez \& Ferreira, 2018). In the Indonesian context, social media is vulnerable to hate speech, affecting attitudes and views on nationalism (Lim, 2017). Furthermore, content or issues in the discussion of netizens on social media lead to discourses on the development of an area (Mpofu, 2019). Studies on the use of information technology, in this case, social media in virtual spaces, are becoming popular. It is essential to identify the correlation between discussion content in virtual areas and their influence on collective action in real space. 
Yerik Afrianto Singgalen:

Actor-Network Theory and Sentiment Analysis on Regional Development Issues and Politics in Social Media

Teori Aktor-Jaringan dan Analisis Sentimen Isu Pembangunan Daerah dan Politik di Media Sosial

Social media is not limited to a rigid virtual space and a place to convey aspirations, as was the case with Al-Arakeeb in Israel (Mpofu, 2019). Community participation in virtual spaces reconstructs new identities known as netizens. The reconstruction of social identities in virtual space reflects the dynamics that indirectly affect community life's whole area (Doron, 2016). The flexibility in virtual space allows the formation of a subjectivity orientation in a gender perspective (Van Vuuren, 2018). Strengthening netizens' subjective direction reflects the freedom of argument that mobilizes aspirations for each region's development process to alleviate various inequality problems, including violence and poverty, through social media monitoring (Luckham, 2018). The intensity of social media use in Indonesia has formed new social formations through networks in virtual spaces that indirectly affect collective action in natural areas, especially in various development issues.

During the Covid-19 pandemic, political activity in North Halmahera Regency seemed to ignore this. It is indicated by the existence of social groups that are still neglecting to implement health protocols. The political moment for the North Halmahera Regency regional head election took place on December 9, 2020, but the campaign has been carried out since November. There are two pairs of regional head candidates based on serial number one (Frans Manery and Muchlis Tapi Tapi) and pair number two (Joel Wogono and Said Bajak). Based on the results of the Regional General Election Commission's calculation in the Plenary Meeting on December 15, 2020, pair number one has 619 votes ahead of pair number two. The process was not over bureaucratically until the regional head general election winner was officially announced by the Regional General Election Commission of North Halmahera Regency.

During the campaign period, each pair of candidates formed a team to support political activities. Groups that are created tend to cluster around and ignore health protocols, despite the government's repeated warnings. On the other hand, social media use has increased because it is used as a campaign medium for each team. In the North Halmahera Quovadis group, the pair number two team (Joel Wogono and Said Bajak) took the opposition's role to criticize the previous government's performance, which was deemed inappropriate. Meanwhile, the pair number one team (Frans Manery and Muchlis Tapi Tapi) was more dominant in providing educational information to reject hoax news, provocative statements, and hate speech. Even though the discussion is in the virtual space, there is an influence on real social area activities. One of them is marked by the mass reaction and response of the supporters of candidate pair number two to the existence of a Facebook account called Tobelo Diorin, which went viral because it published the previous government's performance. Several social spaces in North Halmahera stated that they support Tobelo Diorin in revealing poor government performance to the public through virtual spaces. There has even been a fundraising activity to help Tobelo Diorin and candidate pair number two. It shows that in politics in North Halmahera Regency, various activities in cyberspace also influence social movements in the real world. 
The correlation between the intensity of the use of social media in virtual spaces for monitoring development issues, this study will identify aspects of vulnerability through mapping and classifying netizens' responses in virtual space to various regional development issues based on economic, social, cultural, political, tourism and environmental aspects. Contextually, this research focuses on sentiment analysis through development issues and politics in North Halmahera District, North Maluku Province, Indonesia. Meanwhile, the observation of the virtual interaction space between netizens in discussing development issues. Selectively, the content that is identified as containing the subjective orientation of netizens towards development issues in North Halmahera will be mapped into the following categories: positive responses, hate speech, invalid information (hoax), sarcasm, and bullying. Mapping results were analyzed using Actor-Network Theory's perspective, as in political contestation and Development in China (Poell, de Kloet, \& Zeng, 2014).

Actor-Network Theory views each instrument as having unlimited connectivity and is related to development. Previous researchers used ActorNetwork Theory to analyze various development issues in the economic sector (David \& Halbert, 2014; Korsgaard, 2011), tourism (Van der Duim \& Caalders, 2008), and technology (Wang, Yuan, Turel, \& Tu, 2015). Actor-Network Theory facilitates understanding a method and complex social dynamics (Bussular, Burtet, \& Antonello, 2019). By mapping actor-networks as "agents," it is possible to identify the entity's identity that reflects the nature and prepositions in the constructed relationship (Somerville, 1999). The use of the Actor-Network Theory is relevant to this study's purpose to identify the vulnerability context of the North Halmahera Regency response to regional development issues on social media. Thus, this study's results are expected to contribute to scientific studies in development studies.

\section{Research Methods}

This study uses a qualitative method through a sentiment analysis approach related to regional development issues and North Halmahera Regency's politics on social media. Meanwhile, the theoretical perspective used is ActorNetwork-Theory. This research instrument also uses the Nvivo 12 Plus application to simplify the mapping process based on Actor-Network Theory (ANT) to identify vulnerability aspects. The data collected uses several techniques, namely, in-depth interviews, observation, and document study. Online interviews were conducted with key informants with backgrounds as academics, entrepreneurs in the formal and informal sectors, observers of tourism and the environment, civil servants, and politicians. Interviews with key informants were conducted selectively based on observations. Observation of discussion content is divided into two categories: netizen responses to regional development issues in North Halmahera Regency before and during the Covid-19 pandemic. The qualifications of critical informants are as follows: participating in discussions in virtual rooms through social media; join in communities or organizations related to the social, economic, political, cultural, and environmental fields; The social 
Yerik Afrianto Singgalen:

Actor-Network Theory and Sentiment Analysis on Regional Development Issues and Politics in Social Media

Teori Aktor-Jaringan dan Analisis Sentimen Isu Pembangunan Daerah dan Politik di Media Sosial

media account using a real representation of the true identity of the informant and can be contacted online or face-to-face. Regarding the privacy of key informants, the informants' identity is agreed not to be described in this article. Meanwhile, the context of the research location can be seen in the following figure.

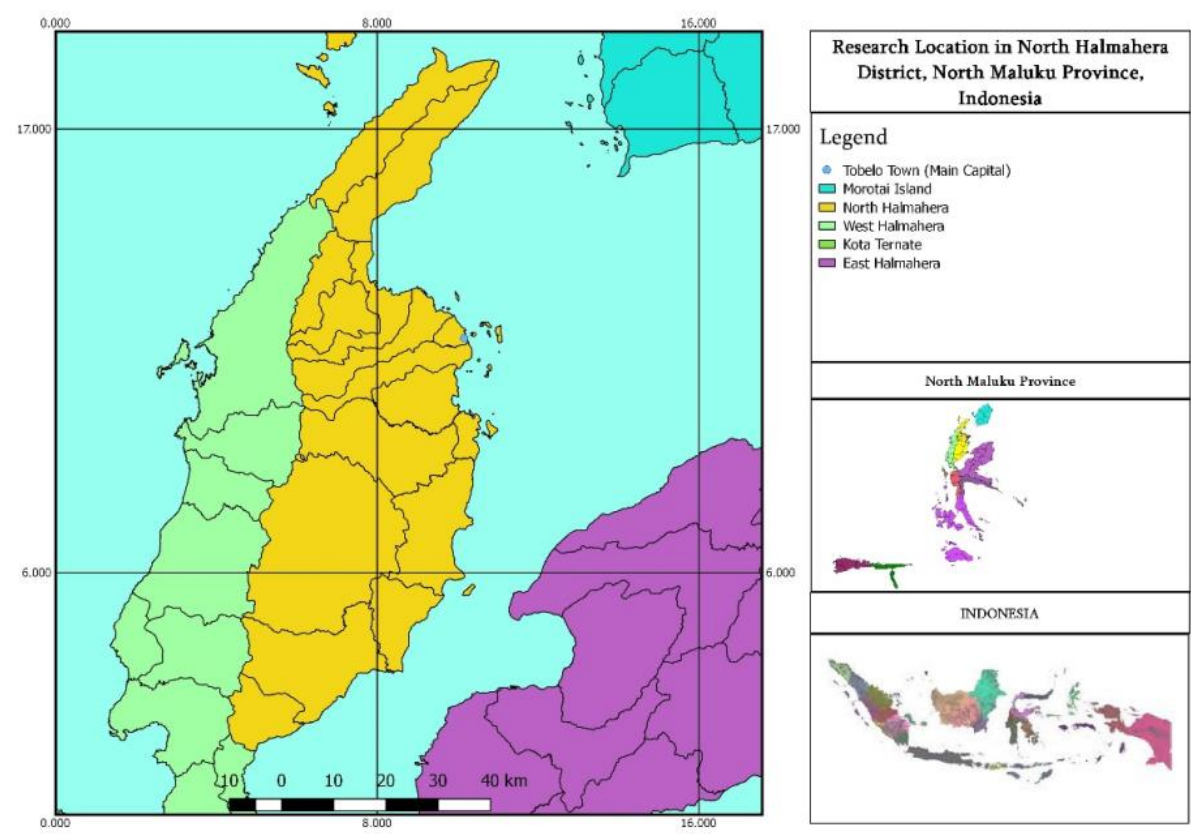

Figure 1: Research locations in North Halmahera District (Source: Results of Satellite Image Digitization using QGIS 2.18.4)

Figure 1 is the context of research on netizens' response to development issues in the North Halmahera Regency. Various development issues discussed in the virtual space are clarified by searching supporting documents to protect the validity of the problems addressed online.

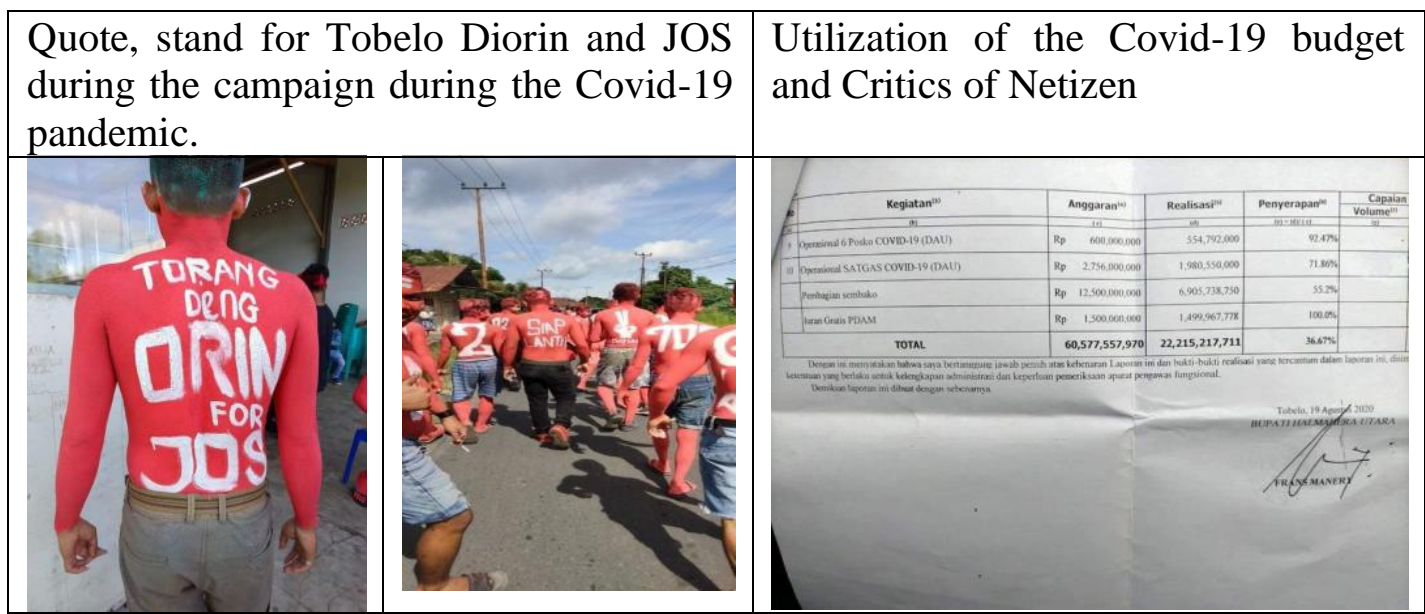

Figure 2: The impact of virtual space on the political and social area in North Halmahera 
The response to regional development issues in virtual space is limited to Development in North Halmahera Regency. The identification and classification of development issues in the North Halmahera Regency before and during the Covid-19 pandemic were managed using triangulation techniques. Data processing using the triangulation approach can maintain the validity and credibility of the data through coherence and correspondence of the results of interviews, observations, and document studies. Furthermore, Actor-Network Theory is used to identify aspects of vulnerability. The research instrument used in the process of mapping development issues is the Nvivo 12 plus. Thus, methodologically, the arguments built on the research framework can be justified.

\section{Result and Discussion}

\section{Regional Development Issues and Politics through Social Media based on} Sentiment Analysis: Case of Quo Vadis Halmahera Utara Facebook Group

The sentiment analysis approach is a new paradigm multiplying in line with the increase in information technology. Sentiment analysis is generally carried out through data mining on the internet to identify positive and negative sentiments based on social media users' comments. This approach is used in determining netizen responses to various topics relevant to economic, sociocultural, political, and environmental aspects (Kennedy, 2012). The sentiment analysis approach can identify net citizens' political choices towards regional leadership candidates based on social media's digital history relevant to personal ideas and opinions on local development issues (José, Oliveira, Henrique, \& Bermejo, 2017). Apart from politics, the sentiment analysis approach is also used to identify netizens' personal opinions on a particular business's products and services. Using sentiment analysis results in customer satisfaction can improve business performance and professionalism in improving the economy (Gan, Ferns, Yu, \& Jin, 2017).

In Indonesia, public participation in virtual spaces through social media increased in line with the Covid-19 pandemic in 2020 (Atsani, 2020; Ferdiana, 2020; Nadeak, Juwita, \& Sormin, 2020; Samsiana et al., 2020; Sutrisna, 2020). An appeal not to crowd, increase the use of social media as a means of communication. However, this did not last long, when the government established a "new normal" as a new order for people to carry out economic, socio-cultural, and political activities, but were obliged to comply with health protocols. The sentiment analysis on various development issues and politics in the Facebook Group "Quo Vadis North Halmahera" shows that negative sentiment is more dominant than a positif sentiment. The dominance of negative opinion on the Facebook Group "Quo Vadis North Halmahera" was indicated by a political moment in the regional head elections, held on December 9, 2020. There are two candidates as local leaders who are organizing campaign activities amid the Covid-19 pandemic. Campaigns are carried out online and are also carried out in real terms. As a result, various negative sentiments on social media have also influenced socio-cultural relationships in everyday life. 
Yerik Afrianto Singgalen:

Actor-Network Theory and Sentiment Analysis on Regional Development Issues and Politics in Social Media

Teori Aktor-Jaringan dan Analisis Sentimen Isu Pembangunan Daerah dan Politik di Media Sosial

Based on the sentiment analysis results on the Facebook Group "Quo Vadis Halmahera Utara," it can be seen that criticism of development was uploaded openly to reap comments from the people of North Halmahera as a form of assessment of the performance of the previous government. Based on the classification of topics and statements uploaded by netizens, the sentiment analysis results show that figures of speech and sentence elements in content and comments can be grouped into hate speech, invalid information, sarcasm, bullying, and privacy attacks. The content uploaded is based on social aspects, culture, economy, environment, politics, education, and health. The issue of government bureaucracy has come to the attention of North Halmahera's people as netizens who can be seen in quantity in the discussion topic uploaded on the Facebook Group "Quo Vadis North Halmahera." The online discussion results have implications for the social life of the people of North Halmahera in providing support in the next regional head election. The use of sentiment analysis through netizen discussions on social media related to politics can offer projections to decision-makers regarding public satisfaction with government programs (Prilani \& Hutomo, 2020; Sabatovych, 2019). Criticism of the government's performance is related to health issues, namely the Covid-19 Handling Task Force's (Gugus Tugas Percepatan Penanganan Covid-19) performance in North Halmahera Regency in carrying out prevention, tracking, handling, and alleviation efforts. As in the following table bellow.

Tabel 1. Post and comment related to the government performance to handle Covid-19 in North Halmahera District

\begin{tabular}{|c|c|c|}
\hline Initial Account & Post and Comment & Date \\
\hline WM & $\begin{array}{l}\text { From March 16, 2020, until today. There is no assistance } \\
\text { from the local government of Halut for the North Loloda } \\
\text { community. I wonder why? }\end{array}$ & $\begin{array}{ll}16 & \text { Mei } \\
2020 & \end{array}$ \\
\hline AS & $\begin{array}{l}\text { The Covid task force, please immediately quarantine one } \\
\text { of the people behind the GOSOMA village office. } \\
\text { According to Info, the mother's husband died on Tuesday } \\
\text { and was a resident of Malefut who also joined the } \\
\text { Dorolonda ship. It is very unsettling for the community }\end{array}$ & $\begin{array}{ll}15 & \text { Mei } \\
2020 & \end{array}$ \\
\hline JK & $\begin{array}{l}\text { Task Force, please act decisively and respond quickly. } \\
\text { Don't just shut up. Worried that if handling is late, many } \\
\text { will be exposed to Covid- } 19 \text {. }\end{array}$ & $\begin{array}{ll}15 & \text { Mei } \\
2020 & \end{array}$ \\
\hline JBM & $\begin{array}{l}\text { agree, but we shouldn't just post on social media. Please } \\
\text { take steps to the village head and report. Then report it to } \\
\text { the task force post at the regent's office. The village head } \\
\text { is also a task force team at the village level. Don't just } \\
\text { post on social media but please be active. }\end{array}$ & $\begin{array}{ll}15 & \text { Mei } \\
2020 & \end{array}$ \\
\hline
\end{tabular}

Table 1 is a brief description based on discussion and comments from netizens on the North Halmahera Regency local government's performance to overcome the Covid-19 pandemic problem. One netizen with the initials WM questioned that the social assistance program was not evenly distributed in the area of origin. Furthermore, netizens with the initials AS, JK, and JBM discussed 
the tendency of one of the residents to escape the tracking process of the Covid-19 task force unit to be examined immediately. Communication in cyberspace is responded to in real terms by reporting it to the Village Head to anticipate negligence in preventing and eradicating the spread of covid-19 in North Halmahera.

The Regional Government is trying to carry out the tracking process until handling patients who are confirmed positive for Covid-19. However, the limited facilities and infrastructure for medical personnel managing Covid-19 have caused several problems, leading to technical negligence. The people of North Halmahera are urged to stay at home and not crowd during the Covid-19 pandemic. Limited social and economic activities have led to an increase in social media use as a means of communication. As netizens who are members of the North Halmahera Quovadis group, North Halmahera's people use it as a communication medium. Netizens are actively sharing information about the government's efforts in handling Covid-19 in North Halmahera Regency. The news in the mass media attracts netizens who stay at home and the following report.

Tabel 2. News about the handling of covid-19 in North Halmahera

\begin{tabular}{|c|c|c|}
\hline Title & Link & Editor \\
\hline $\begin{array}{l}\text { North Halmahera } \\
\text { Covid-19 Task Force } \\
\text { Admits Negligence at } \\
\text { the Beginning }\end{array}$ & $\begin{array}{l}\text { https://www.gatra.com/detail/news/477467/mileni } \\
\text { al/satgas-covid-19-halmahera-utara-akui-lalai-di- } \\
\text { awal }\end{array}$ & $\begin{array}{l}\text { Zairin } \\
\text { Salampess } \\
\text { y }\end{array}$ \\
\hline $\begin{array}{l}\text { Director of Tobelo } \\
\text { Hospital Infected with } \\
\text { Covid-19 }\end{array}$ & $\begin{array}{l}\text { https://www.medcom.id/nasional/daerah/VNx4EQ } \\
\text { gN-direktur-rsud-tobelo-terinfeksi-covid-19 }\end{array}$ & $\begin{array}{l}\text { Hijrah } \\
\text { Ibrahim }\end{array}$ \\
\hline $\begin{array}{l}12 \text { Medical Personnel } \\
\text { at Tobelo Hospital, } \\
\text { North } \quad \text { Maluku } \\
\text { Positive for Covid-19 }\end{array}$ & $\begin{array}{l}\text { https://regional.kompas.com/read/2020/08/27/2003 } \\
\text { 0231/12-tenaga-medis-di-rsud-tobelo-maluku- } \\
\text { utara-positif-covid-19 }\end{array}$ & $\begin{array}{l}\text { Dheri } \\
\text { Agriesta }\end{array}$ \\
\hline $\begin{array}{l}\text { Secretary of } \begin{array}{r}\text { North } \\
\text { Halmahera }\end{array} \\
\text { and } \\
\text { Chinese citizens died } \\
\text { due to Covid-19 }\end{array}$ & $\begin{array}{l}\text { https://mediaindonesia.com/nusantara/338527/sekd } \\
\text { a-halmahera-utara-dan-wn-tion } \\
\text { karena-covid-19 }\end{array}$ & $\begin{array}{l}\text { Hijrah } \\
\text { Ibrahim }\end{array}$ \\
\hline $\begin{array}{l}\text { Positive Corona, } 12 \\
\text { Medical Personnel at } \\
\text { Tobelo Hospital, are } \\
\text { Quarantined }\end{array}$ & $\begin{array}{l}\text { https://www.antaranews.com/berita/1613630/255- } \\
\text { karyawan-yang-terpapar-covid-19-di-halmahera- } \\
\text { utara-sudah-sembuh }\end{array}$ & $\begin{array}{l}\text { Abdul } \\
\text { Fatah }\end{array}$ \\
\hline $\begin{array}{l}\text { Positive Covid-19, } \\
\text { Secretary of North } \\
\text { Halmahera Died in } \\
\text { Manado }\end{array}$ & $\begin{array}{l}\text { https://www.liputan6.com/regional/read/4336626/ } \\
\text { positif-covid-19-sekda-halmahera-utara- } \\
\text { meninggal-di-manado }\end{array}$ & $\begin{array}{l}\text { Yoseph } \\
\text { Ikanubun }\end{array}$ \\
\hline $\begin{array}{l}\text { Many } \\
\text { Workers Are Exposed } \\
\text { to Covid-19, Tobelo } \\
\text { Hospital Services } \\
\text { Discontinued }\end{array}$ & $\begin{array}{l}\text { https://tekno.tempo.co/read/1382170/banyak- } \\
\text { tenaga-medis-terpapar-covid-19-layanan-rumah- } \\
\text { sakit-tobelo-dihentikan }\end{array}$ & $\begin{array}{l}\text { Erwin } \\
\text { Prima }\end{array}$ \\
\hline
\end{tabular}


Yerik Afrianto Singgalen:

Actor-Network Theory and Sentiment Analysis on Regional Development Issues and Politics in Social Media

Teori Aktor-Jaringan dan Analisis Sentimen Isu Pembangunan Daerah dan Politik di Media Sosial

Table 2 is news regarding developments in the handling of covid-19 in North Halmahera Regency. North Halmahera's people experienced grief when one of the regional officials with the initials FT who served as the provincial secretary died due to Covid-19. FT takes an active role in efforts to deal with the Covid-19 problem in North Halmahera Regency. The increase in the number of patients confirmed positive for Covid-19 in North Halmahera, apart from disturbing the public, also caused negative sentiment towards the Covid-19 handling task force's performance. Negative emotion is dominant because the government's performance is considered not optimal. It is detrimental to the public when there is an increase in the number of positive patients with Covid-19 in North Halmahera regency. The use of sentiment analysis is also carried out to identify the pandemic's impact on people's livelihoods globally through a new work pattern, namely Working From Home (WFH) (Wrycza \& Maślankowski, 2020). Indonesia's problem, especially North Halmahera Regency, is the limited internet access in the border area. Also, most people's livelihoods depend on agricultural businesses, which cannot be done online with the concept of Work From Home (WFH). Also, the people of North Halmahera's work pattern, known as cooperation (Hirono), consists of workgroups based on local cultures that allow physical and face-to-face contact (Singgalen, 2020; Singgalen, Sasongko, \& Wiloso, 2019b). In the Covid-19 pandemic conditions, farmers' work pattern is hazardous and can increase the transmission of covid-19 in the North Halmahera Regency. Livelihood conditions that are not in sync with the WFH concept are the government's consideration to direct the covid-19 handling program to herd immunity, namely increasing the immunity of local communities to the susceptibility of covid-19 infection.

Negative sentiment has increased in discussions about local governments' performance, especially in dealing with Covid-19 and various other issues such as socio-cultural, economic, environmental, and political issues. Different discussion content on the Facebook Group "Quo Vadis Halmahera Utara" influenced the brotherly relations of the people of North Halmahera when they entered political moments. Differences in political choices lead to social segregation and negative sentiment in various comments containing hate speech, invalid information, sarcasm, bullying, and privacy attacks. The interaction of netizen relations on social media has a significant influence on community relations in everyday life.

\section{Regional Development Issues and Politics through Social Media Based on Actor-Network Theory: Case of North Halmahera District, North Maluku Province, Indonesia}

The development of development studies in various dynamic and contextual issues cannot be separated from the socio-cultural, economic, environmental, and political aspects. Studies on the complexity of development in different socio-cultural contexts show elements of a vulnerability that lead to conflict (Ekstrand \& Ray, 2001). The key to social problems is crucial because it influences family livelihoods and citizens (Moloney, Weston, \& Hayes, 2013). Also, vulnerable economic issues affect the sustainability of development in a region or country. Apart from socio-economic problems, political problems in 
each area also significantly affect criticism as a response to development issues. The space for expressing opinions about development administrators' performance has developed along with the intense use of technology. Depending on official forums held in real rooms, discussions also occur online in virtual rooms according to the category of discussion rooms on social media. "Quo Vadis Halmahera Utara" is one of the discussion spaces that trigger community participation in North Halmahera Regency as netizens to discuss regional development problems based on social aspects, culture, economy, environment, politics, education, and health. The results of content identification and mapping in the virtual discussion group of "Quo Vadis Halmahera Utara" based on the Actor-Network Theory using Nvivo 12 plus are in the following figure.

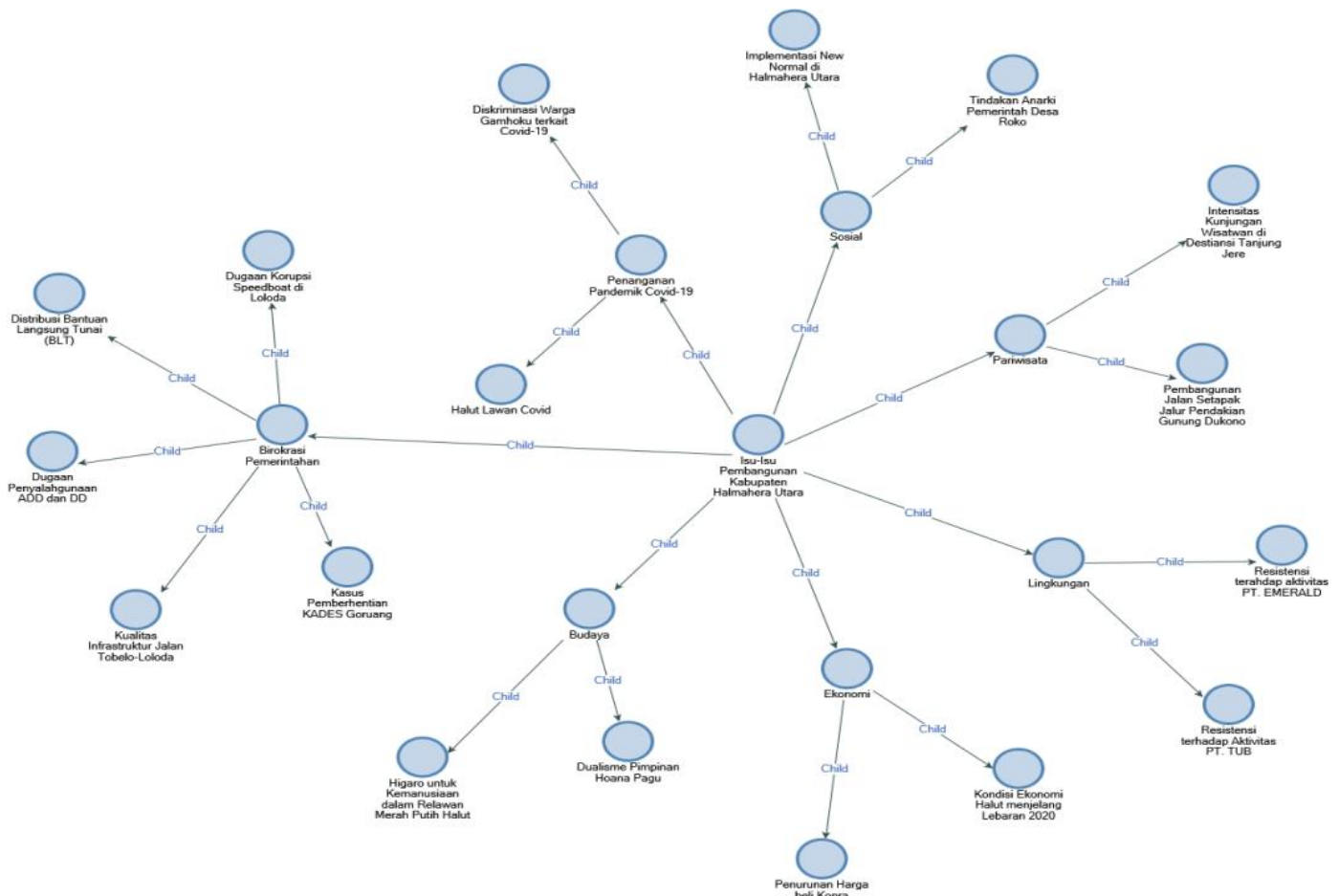

Figure 2: Results of Content Identification and Netizen Interaction Behavior In A Virtual Discussion Room

(Source: Primary data processing results using Nvivo 12 Plus)

Figure 2 results from the identification and mapping of development issues discussed by North Halmahera Regency's people as netizens in Quo Vadis North Halmahera's virtual discussion room. The most dominant content discussed was related to development, before the Covid-19 pandemic was related to economic and political issues. After the 2016 regional head election and the decline in copra prices, the political conditions, which led to demonstrations at the North Halmahera Regent's office, became popular discussion content. During the Covid19 pandemic, the local government's performance was of concern to North Halmahera's people as netizens. Netizens' concern about the distribution of Direct Cash Assistance (Bantuan Langsung Tunai) and various large-scale social restriction policies (Kebijakan Pembatasan Sosial Skal Besar) have implications 
Yerik Afrianto Singgalen:

Actor-Network Theory and Sentiment Analysis on Regional Development Issues and Politics in Social Media

Teori Aktor-Jaringan dan Analisis Sentimen Isu Pembangunan Daerah dan Politik di Media Sosial

for social and economic activities in North Halmahera. Comparing the popularity of discussion content in virtual spaces reflects North Halmahera residents' responsiveness as social media users to guard the regional development process. Even so, the results of mapping and analysis of netizen interaction behavior in the Quo Vadis Halmahera Utara group based on the Actor-Network Theory show the potential for social conflict from virtual to real space. Meanwhile, the mapping and analysis of netizen interaction behavior in virtual space can be seen in Figure 3 below.

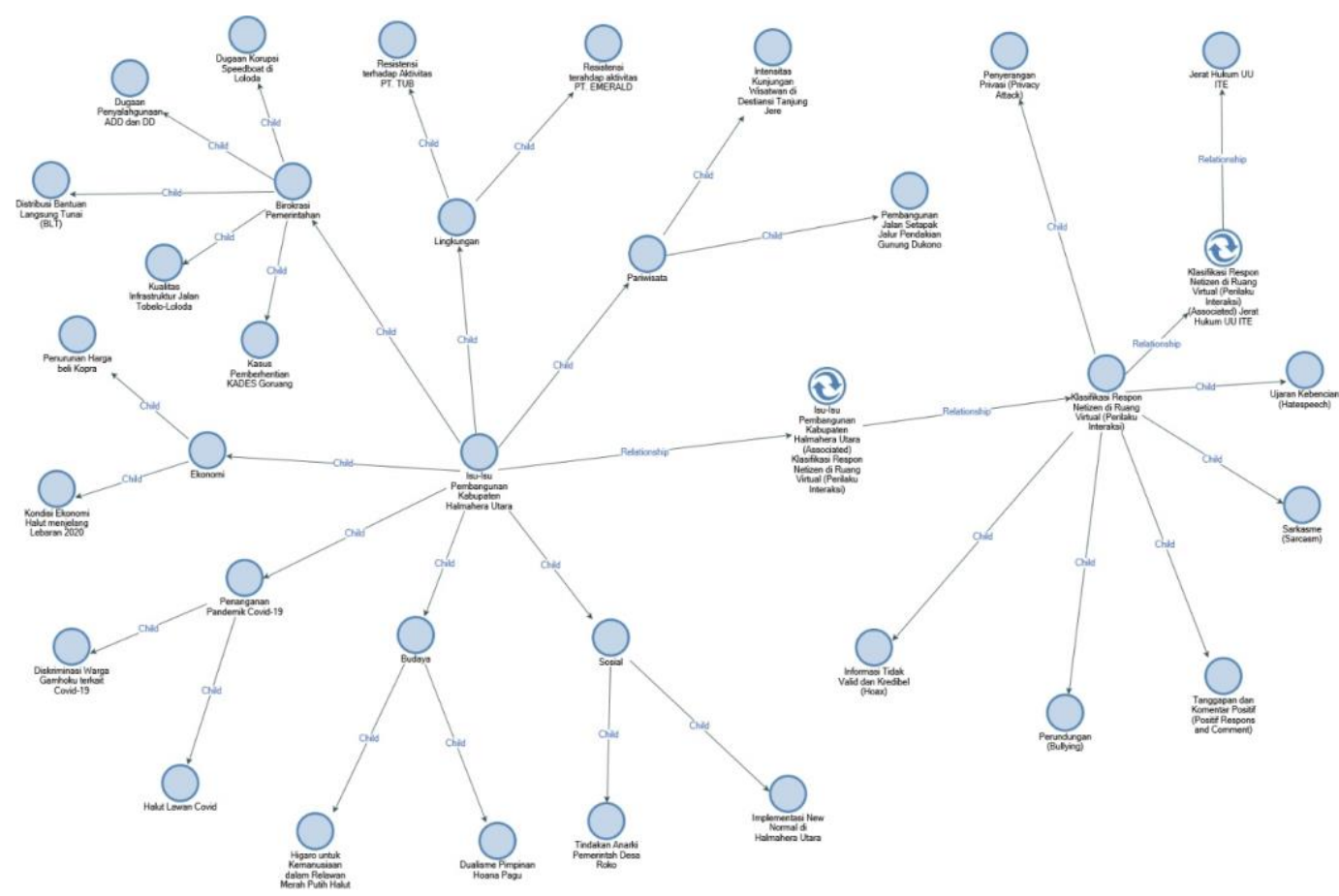

Figure 3: Results of Mapping and Analysis of Netizen Behavior in Virtual Space (Source: Primary data processing results using Nvivo 12 Plus)

Figure 3 shows that various development issues and the response of netizens as actors can be mapped as follows: positive reactions and comments (Positive responses and comments), hate speech, invalid information, sarcasm, bullying, privacy attacks. The content analysis shows aspects of vulnerability to social capital such as Norms, Trusts, and Networks. It appears when virtual areas debate lead to the snare of the Law on Information and Electronic Transactions (Undang-Undang Informatika dan Teknologi Elektronik). An obstacle in content management is participants' standards and qualifications to join and argue in the Quo Vadis Halmahera Utara Group. It has implications for conflict opportunities in the virtual area due to content and comments that contain elements of violations of the ITE Law. The pros and cons of users of social media accounts that do not represent real identities (fake accounts) spark debates in virtual spaces into conflicts in natural spaces. It shows that netizens' interaction in the virtual space affects social formation in natural areas, as in Paul Kostan Simonda's reporting as 
Jeffry Rudy Hoata's attorney against several netizens in the Quo Vadis Halmahera Utara Group for alleged slander through social media. In this case, the privacy attack took place in the Quo Vadis Halmahera Utara Group. Rachman Baba covered the news about the issue via online information halmaheraraya.com on Friday, June 19, 2020.

Netizen interaction in virtual space is not constrained by time and space. The technological devices used to support social media applications are borderless and real-time, thereby mobilizing netizen communication in virtual areas. In discussing development issues in virtual spaces, networking netizens form new social formations in virtual spaces prone to legal problems (Santoso, 2014; Tylec \& Szegda, 2020). Various previous research results show that virtual areas' conflicts affect relationships between individuals and groups in the real world (Browne, Stack, \& Ziyadah, 2015). Therefore, institutionally, public relations need to be maintained with a more adaptive and responsive approach based on popularity (Jiang, Luo, \& Kulemeka, 2017). Conflict vulnerability in the virtual space is not only influenced by the emotions of social media account users but also the content of narratives published in the virtual space (Kusumasari \& Arifianto, 2019; Roluahpuia, 2017). Therefore, the publication of various development content through social media in virtual spaces needs to be carried out selectively (Djerf-Pierre, Ghersetti, \& Hedman, 2016). Some companies that adopt social media as a product marketing strategy provide institutional support to manage conflicts based on the characteristics of corporate interests (Dineva, Breitsohl, \& Garrod, 2017). In the context of this research, various development issues in North Halmahera Regency are not mobilized based on corporations but individual initiatives to discuss development progress in North Halmahera Regency through the Quo Vadis North Halmahera discussion room. Based on Actor-Network Theory analysis, actor classification is not limited to netizens but also the most crucial element in the discussion, namely content. The ActorNetwork Theory content triggers netizens' thinking with the accumulated experience and understanding relevant to the content.

The response to various development issues in virtual space manifests the accumulated experiences and subjective knowledge of netizens. Different subjective-oriented views in responding to one development content can lead to pros and cons among netizens. Ethical issues, in the comment, tend to be a reference in netizen debates. Still, differences in opinions can be responded to as provocative statements that lead to virtual space conflicts. Therefore, the ActorNetwork Theory approach facilitates the mapping and analysis of netizen interactions based on responses to regional development issues (Gershon \& Malitsky, 2015). In Actor-Network Theory, the definition of an actor is very dynamic and contextual. Several previous studies used the Actor-Network Theory approach in analyzing the epistemological aspects of the education system (Fenwick, 2010). Actor-Network Theory was used to analyze the relationship between technology and religion (Checketts, 2017). Actor-Network Theory can also be used to map and analyze netizen responses to complex, dynamic, and contextual development issues in virtual space. This research indicates that the 
Yerik Afrianto Singgalen:

Actor-Network Theory and Sentiment Analysis on Regional Development Issues and Politics in Social Media

Teori Aktor-Jaringan dan Analisis Sentimen Isu Pembangunan Daerah dan Politik di Media Sosial

answer to regional development issues in the virtual space is vulnerable to social capital degradation, namely, trust, norms, and networks.

Social capital has a significant role for the people of North Halmahera. A communal society's characteristics based on cultural norms that form social formations in Higaro's local wisdom should maintain the integrity (Аһuитu) of the accumulation of social networks based on cultural norms in various spaces. In a study of North Halmahera's livelihoods, social capital plays an essential role in Development (Singgalen, 2020; Singgalen et al., 2019b). Various cultural rituals of North Halmahera's people form social formations based on local wisdom such as Hirono, Makiriwo, Balelan, Babari, and various forms of solidarity and encourage participation in institutional Development (Singgalen, Sasongko, \& Wiloso, 2019a). The conflict between North Halmahera's people as users of social media accounts (netizens) in real space impacts the accumulation of culture-based social networks. In Actor-Network Theory, every actor is connected and influences each other. Social capital degradation also affects various aspects of development, such as economic aspects. Previous studies have shown that social capital is a shadow of the economy (Evans, 2016; Lee, 2013). Economic Development and political intervention by social capital are also the researchers' attention in studies of the development of disadvantaged areas to poverty (du Toit, Skuse, \& Cousins, 2007). Social capital is a central issue as the basis for economic knowledge (Sporer, 2004). Norms, networks, and trust as formations of social capital need to be protected not to experience degradation when facing various vulnerability aspects. This research shows that content containing hate speech elements, invalid credible information (hoax), sarcasm, bullying, and privacy attacks are the potential actors to cause social capital degradation based on the Actor-Network-Theory.

\section{Conclusion}

This study indicates that social capital (norms, trust, and networks) is an aspect of vulnerability. Based on the results of sentiment analysis in the form of mapping on community responses to development issues in North Halmahera Regency, it can be seen that social media applications allow people as netizens or application users to be more responsive. The intensity of social media users causes development issues to fluctuate based on popularity (trend). The response to development issues in the conditions before and during the Covid-19 pandemic. Based on the Actor-Network Theory, netizens act as actors who have unlimited capabilities to build social networks with other actors in a virtual space. Various development issues and netizen responses as actors can be mapped into the following categories: positive response and comments, hate speech, invalid information (hoax), sarcasm, bullying, and privacy attacks. The popularity of issues that are relevant to current conditions can increase netizen participation in arguments. Still, content control and negative responses are vulnerable to uncontrolled, so they are prone to causing legal problems under the Law on Information and Electronic Transactions (UU ITE). It causes social capital to 
become an aspect of vulnerability in various virtual space responses to regional development dynamics.

The recommendations of this study's results are to become the local government's attention regarding the importance of the results of the analysis of the sentiment of the North Halmahera community through social media. The opposing view dramatically affects the image of North Halmahera's bureaucracy, reflecting the sub-optimal performance of local governments in development. North Halmahera people's social interactions on social media have implications for movements in social and cultural spaces. It shows the existence of various potential conflicts triggered by provocative issues in the virtual space. Even though the tendency to reject hoax news has campaigned on social media, there needs to be a critical effort from the local government to anticipate various development issues that have been politicized to cause horizontal conflicts among the people of North Halmahera.

\section{Acknowledgement}

I would like to thank the various parties who supported this research process up to the publication stage. Thanks to the Atma Jaya Catholic University of Indonesia and Regional Higher Education Service Institute (LLDIKTI III)

\section{Reference}

Atsani, L. G. M. Z. (2020). Transformasi Media Pembelajaran Pada Masa Pandemi Covid-19. Jurnal Teknologi Pendidikan, 22(1), 65-70. Retrieved from http://journal.unj.ac.id/unj/index.php/jtp

Bratich, J. (2014). Occupy All the Dispositifs: Memes, Media Ecologies, and Emergent Bodies Politic. Communication and Critical/ Cultural Studies, 11(1), 64-73. https://doi.org/10.1080/14791420.2013.827351

Browne, M., Stack, L., \& Ziyadah, M. (2015). Streets to screens: conflict, social media and the news. Information Communication and Society, 18(11), 1339-1347. https://doi.org/10.1080/1369118X.2015.1071862

Bussular, C. Z., Burtet, C. G., \& Antonello, C. S. (2019). The actor-network theory as a method in the analysis of Samarco disaster in Brazil. Qualitative Research in Organizations and Management: An International Journal, 15(2), 176-191. https://doi.org/10.1108/QROM-04-2017-1520

Checketts, L. (2017). The cross and the computer: Actor-network theory and Christianity. Theology and Science, 15(1), 116-127. https://doi.org/10.1080/14746700.2016.1265223

David, L., \& Halbert, L. (2014). Finance Capital, Actor-Network Theory and the Struggle Over Calculative Agencies in the Business Property Markets of Mexico City Metropolitan Region. Regional Studies, 48(3), 516-529. https://doi.org/10.1080/00343404.2012.756581 
Yerik Afrianto Singgalen:

Actor-Network Theory and Sentiment Analysis on Regional Development Issues and Politics in Social Media

Teori Aktor-Jaringan dan Analisis Sentimen Isu Pembangunan Daerah dan Politik di Media Sosial

Dineva, D. P., Breitsohl, J. C., \& Garrod, B. (2017). Corporate conflict management on social media brand fan pages. Journal of Marketing Management, 33(9-10), 679-698. https://doi.org/10.1080/0267257X.2017.1329225

Djerf-Pierre, M., Ghersetti, M., \& Hedman, U. (2016). Appropriating Social Media: The changing uses of social media among journalists across time. Digital Journalism, 4(7), 849-860. https://doi.org/10.1080/21670811.2016.1152557

Doron, A. (2016). Unclean, unseen: Social media, civic action and urban hygiene in India. South Asia: Journal of South Asia Studies, 39(4), 715-739. https://doi.org/10.1080/00856401.2016.1218096

du Toit, A., Skuse, A., \& Cousins, T. (2007). The political economy of social capital: Chronic poverty, remoteness and gender in the rural Eastern Cape. Social Identities, 13(4), 521-540. https://doi.org/10.1080/13504630701459180

Ekstrand, L. H., \& Ray, R. (2001). Chaos and complexity in development. International Journal of Sustainable Development and World Ecology, 8(2), 127-136. https://doi.org/10.1080/13504500109470070

Evans, M. (2016). Social Capital and the Shadow Economy. Journal of Economic Issues, 50(1), 43-58. https://doi.org/10.1080/00213624.2016.1147304

Fenwick, T. J. (2010). (un)Doing standards in education with actor-network theory. Journal of Education Policy, 25(2), 117-133. https://doi.org/10.1080/02680930903314277

Ferdiana, S. (2020). Persepsi Mahasiswa tentang Penggunaan Media Daring pada Program Studi S1 Ilmu Gizi Sekolah Tinggi Ilmu Kesehatan Surabaya selama Masa Pandemi Corona Virus Disease (COVID-19). Indonesian Journal of Science Learning, 1(1), 5-12.

Gan, Q., Ferns, B. H., Yu, Y., \& Jin, L. (2017). A Text Mining and Multidimensional Sentiment Analysis of Online Restaurant Reviews. Journal of Quality Assurance in Hospitality \& Tourism, 18(4), 465-492. https://doi.org/10.1080/1528008X.2016.1250243

Gershon, I., \& Malitsky, J. (2015). Actor-network theory and documentary studies Actor-network theory and documentary studies, 3280(September), 37-41. https://doi.org/10.1386/sdf.4.1.65

Großmann, K. (2018). Social Media and the Successful Anti-Mining Campaign in Bangka, Indonesia. Journal of Contemporary Asia, 48(5), 835-854. https://doi.org/10.1080/00472336.2018.1432675

Gyampo, R. E. Van. (2017). Social media, traditional media and party politics in Ghana. Africa Review, 9(2), 125-139. https://doi.org/10.1080/09744053.2017.1329806

Halim, W. (2018). Young Islamic preachers on Facebook: Pesantren As'adiyah and its engagement with social media. Indonesia and the Malay World, 46(134), 44-60. https://doi.org/10.1080/13639811.2018.1416796

Hew, W. W. (2018). THE ART OF DAKWAH: social media, visual persuasion and the Islamist propagation of Felix Siauw. Indonesia and the Malay World, 46(134), 61-79. https://doi.org/10.1080/13639811.2018.1416757 
Jiang, H., Luo, Y., \& Kulemeka, O. (2017). Strategic Social Media Use in Public Relations: Professionals' Perceived Social Media Impact, Leadership Behaviors, and Work-Life Conflict. International Journal of Strategic Communication, $11(1)$, $18-41$. https://doi.org/10.1080/1553118X.2016.1226842

José, D., Oliveira, S., Henrique, P., \& Bermejo, D. S. (2017). Can social media reveal the preferences of voters? A comparison between sentiment analysis and traditional opinion polls. Journal of Information Technology \& Politics, 14(1), 34-45. https://doi.org/10.1080/19331681.2016.1214094

Kartikatantri, A. D., Hafiar, H., \& Priyatna, C. C. (2015). Perbedaan Sikap Pemilih Pemula Antara Peserta Dan Bukan Peserta " Roadshow Pendidikan Pemilu ." Jurnal Komunikasi, 7/1, 26-40.

Kennedy, H. (2012). Perspectives on Sentiment Analysis. Journal of Broadcasting \& Electronic, 56(4), 435-450. https://doi.org/10.1080/08838151.2012.732141

Korsgaard, S. (2011). Opportunity formation in social entrepreneurship. Journal of Enterprising Communities, 5(4), 265-285. https://doi.org/10.1108/17506201111177316

Kusumasari, D., \& Arifianto, S. (2019). Makna Teks Ujaran Kebencian Pada Media Sosial | Kusumasari | Jurnal Komunikasi. Jurnal Komunikasi, 12(1), $1-15$. Retrieved

from https://journal.untar.ac.id/index.php/komunikasi/article/view/4045/4661

Lee, D. (2013). How Does Social Capital Reduce the Size of the Shadow Economy? Global Economic Review, 42(3), 251-268. https://doi.org/10.1080/1226508X.2013.833846

Lim, M. (2013). Many Clicks but Little Sticks: Social Media Activism in Indonesia. Journal of Contemporary Asia, 43(4), 636-657. https://doi.org/10.1080/00472336.2013.769386

Lim, M. (2017). Freedom to hate: social media, algorithmic enclaves, and the rise of tribal nationalism in Indonesia. Critical Asian Studies, 49(3), 411-427. https://doi.org/10.1080/14672715.2017.1341188

Luckham, R. (2018). Building inclusive peace and security in times of unequal development and rising violence. Peacebuilding, 6(2), 87-110. https://doi.org/10.1080/21647259.2018.1449185

Molaei, H. (2015). Discursive opportunity structure and the contribution of social media to the success of social movements in Indonesia. Information Communication and Society, 18(1), 94-108. https://doi.org/10.1080/1369118X.2014.934388

Moloney, L., Weston, R., \& Hayes, A. (2013). Key social issues in the development of Australian family law: Research and its impact on policy and practice1. Journal of Family Studies, 19(2), 110-138. https://doi.org/10.5172/jfs.2013.19.2.110

Mpofu, S. (2019). For a nation to progress victims must 'move on': a case of Zimbabwe's social media discourses of Gukurahundi genocide silencing and resistance. African Identities, 17(2), 108-129. https://doi.org/10.1080/14725843.2019.1660618 
Yerik Afrianto Singgalen:

Actor-Network Theory and Sentiment Analysis on Regional Development Issues and Politics in Social Media

Teori Aktor-Jaringan dan Analisis Sentimen Isu Pembangunan Daerah dan Politik di Media Sosial

Nadeak, B., Juwita, C. P., \& Sormin, E. (2020). Korelasi Kemampuan Berpikir Kritis Mahasiswa dan Penggunaan Media Sosial terhadap Capaian Pembelajaran pada Masa Pandemi Covid-19. Jurnal Konseling Dan Pendidikan, 8(2), 98. https://doi.org/10.29210/146600

Poell, T., de Kloet, J., \& Zeng, G. (2014). Will the real Weibo please stand up? Chinese online contention and actor-network theory. Chinese Journal of Communication. Taylor \& Francis. https://doi.org/10.1080/17544750.2013.816753

Prilani, P., \& Hutomo, S. B. H. (2020). Konfigurasi Komunikasi Politik atas Fenomena Calon Tunggal Pada Pilkada Kabupaten Kediri Tahun 2020. Jurnal Komunikasi, 12(2), 282. https://doi.org/10.24912/jk.v12i2.9624

Rodríguez, M. D., \& Ferreira, J. (2018). The contribution of the intervention in social networks and community social work at the local level to social and human development. European Journal of Social Work, 21(6), 863-875. https://doi.org/10.1080/13691457.2018.1423551

Roluahpuia. (2017). Media in conflict or conflict in media: examining media coverage of conflict in Northeast India. Asian Ethnicity, 18(4), 488-504. https://doi.org/10.1080/14631369.2016.1219224

Sabatovych, I. (2019). Use of Sentiment Analysis for Predicting Public Opinion on Referendum: A Feasibility Study. The Reference Librarian, 60(3), 202-211. https://doi.org/10.1080/02763877.2019.1595260

Samsiana, S., Herlawati, Nidaul Khasanah, F., Trias Handayanto, R., Setyowati Srie Gunarti, A., Irwan Raharja, ... Benrahman. (2020). Pemanfaatan Media Sosial dan Ecommerce Sebagai Media Pemasaran Dalam Mendukung Peluang Usaha Mandiri Pada Masa Pandemi Covid 19. Jurnal Sains Teknologi Dalam Pemberdayaan Masyarakat, 1(1), 51-62. https://doi.org/10.31599/jstpm.v1i1.255

Santoso, D. H. (2014). Media Dan Politik: Pertarungan Ruangn \& Kuasa Media Menjelang Pemilihan Presiden. Jurnal Komunikasi Untar, 6(2), 42-47.

Singgalen, Y. A. (2020). Intensification of Social Capital through Ritual Capital. Sodality: Jurnal Sosiologi Pedesaan, 08(01), 82-104. https://doi.org/10.22500/8202029421

Singgalen, Y. A., Sasongko, G., \& Wiloso, P. G. (2019a). Community Participation in Festival and Digital Tourism Campaign (Case of North Halmahera District, Indonesia). Journal of Indonesian Tourism and Development Studies, 7(1), 21-31. https://doi.org/10.21776/ub.jitode.2019.007.01.04

Singgalen, Y. A., Sasongko, G., \& Wiloso, P. G. (2019b). Ritual Capital for Rural Livelihood and Sustainable Tourism Development in Indonesia. Jurnal Manajemen Hutan Tropika (Journal of Tropical Forest Management), 25(2), 115-125. https://doi.org/10.7226/jtfm.25.2.115

Somerville, I. (1999). Agency versus identity: Actor-network theory meets public relations. Corporate Communications: An International Journal, 4(1), 613. https://doi.org/10.1108/13563289910254525 
Sporer, Z. (2004). Knowledge-based economy and social capital in Central and East European countries. Eastern European Economics, 42(6), 39-71. https://doi.org/10.1080/00128775.2004.11041092

Sutrisna, I. P. G. (2020). Gerakan Literasi Digital Pada Masa Pandemi Covid-19. Stilistika: Jurnal Pendidikan Bahasa Dan Seni, 8(2), 268-283. https://doi.org/10.5281/zenodo.3884420

Tylec, G., \& Szegda, J. (2020). A virtual grave: legal regulations of a new virtual social phenomenon. Information and Communications Technology Law, 29(2), 135-150. https://doi.org/10.1080/13600834.2020.1732037

Van der Duim, V. R., \& Caalders, J. (2008). Tourism chains and pro-poor tourism development: An actor-network analysis of a pilot project in Costa Rica. Current Issues in Tourism, 11(2), 109-125. https://doi.org/10.2167/cit312.0

Van Vuuren, M. (2018). Social media, dress and body marking: exploring young women's imaginative, "languages of the self." Agenda, 32(3), 21-38. https://doi.org/10.1080/10130950.2018.1499307

Wang, Y., Yuan, Y., Turel, O., \& Tu, Z. (2015). Understanding the development and diffusion of mobile commerce technologies in China: A biographical study with an actor-network theory perspective. International Journal of Electronic Commerce, 19(4), 47-76. https://doi.org/10.1080/10864415.2015.1029358

Wrycza, S., \& Maślankowski, J. (2020). Social Media Users 'Opinions on Remote Work during the COVID-19 Pandemic . Thematic and Sentiment Analysis Social Media Users ' Opinions on Remote Work during the COVID-19 Pandemic . Information Systems Management, 00(00), 1-10. https://doi.org/10.1080/10580530.2020.1820631 